This is the penultimate version (July 2018) of a paper to appear in Journal of Cultural Cognitive Science. Please cite the final, published version if possible.

\title{
Immorality and $\mathrm{Bu}$ Daode, Unculturedness and $\mathrm{Bu}$ Wenming
}

\author{
Vilius Dranseika ${ }^{1,2}$; Renatas Berniūnas ${ }^{2,3}$; Vytis Silius ${ }^{2}$ \\ ${ }^{1}$ Institute of Philosophy, Vilnius University \\ ${ }^{2}$ Institute of Asian and Transcultural Studies, Vilnius University \\ ${ }^{3}$ Institute of Psychology, Vilnius University
}

\begin{abstract}
In contemporary Western moral philosophy literature that discusses the Chinese ethical tradition, it is a commonplace practice to use the Chinese term daode 道德 as a technical translation of the English term moral. The present study provides some empirical evidence showing a discrepancy between the terms moral and daode. There is a much more pronounced difference between prototypically immoral and prototypically uncultured behaviors in English (USA) than between prototypically bu daode 不道德 and prototypically bu wenming 不文明 behaviors in Mandarin Chinese (Mainland China). If the Western concept of immorality is defined in contraposition to things that are matters of etiquette or conventional norms and thus tied to a more or less tangible moral / conventional distinction, then we are dealing with a different structure in Mandarin Chinese - the prototypically $b u$ daode and bu wenming behaviors seem to largely overlap. We also discuss whether bu lunli 不倫理 and bu hefa 不合法 can be considered adequate candidates for translation of immorality and we answer in the negative.
\end{abstract}

Keywords: Normative domains, morality, daode, moral philosophy, moral psychology, cross-cultural studies 


\section{Introduction}

In contemporary Western moral philosophy literature that discusses Chinese ethical tradition, it is a commonplace practice to use the Chinese term daode 道德 as a technical translation of the English term moral. Such usage is supported by references to dictionaries; these terms seem to be used interchangeably by bilinguals (Buchtel et al. 2015), and it is also endorsed by contemporary Chinese academic authors writing about daode or lunli 倫理 (ethical) (Gao 2005). At the same time, many authors also notice problems with equating morality, as it is usually understood in the Western literature, with daode. Kupperman (2002) pointed out that for early Confucians, questions of style - usually understood as primarily an aesthetical concern - would be an important part in considerations on good life and character and / or right action, thus in practice functioning as a moral concern in the Western sense of the term. Rosemont (1976) suggested that early Confucians did not distinguish the specifically moral sphere of human reality as separated from other normative domains. He encourages everyone to accept the thesis that there "are no unique concepts of morals, moral actions, or moral dilemmas in early Confucianism" without in any way implying that this is a philosophical defect. On the contrary, Rosemont seems to suggest that understanding the unique patterns of early Confucian normative categorizations would provide us with broader and less culturebound perspectives in moral philosophy and psychology (Rosemont 1976, 50). Additionally, in fact, recent studies in comparative moral psychology provide some empirical evidence showing a discrepancy between the English term moral and the Chinese term daode, indicating that violations of conventional norms of civilized or cultured behavior in everyday Chinese usage are conceptualized as bu daode 不道德, or, if we agree with the dictionaries and academic convention, immoral acts (Buchtel et al. 2015). In the present article, we intend to contribute to this discussion on the meaning of the terms morality and bu daode. We believe that these questions are not only interesting in their own right as questions of lexical 
semantics, but that they can also have implications for descriptive projects in Moral Psychology and Moral Philosophy, and that they can inform choices made in translation.

\section{Daode 道德}

The contemporary Chinese term daode is a compound of two important, rich, and not easily translatable terms of the early Chinese thought tradition. The term dao 道 literally means "road, path, way". In its broader sense, it also means a way or method, art, teachings of being, acting, and functioning (Ames and Rosemont 1998). The term de 德 - commonly translated as "virtue", "power", or "potency" - in its earliest usages has denoted a nonphysical and non-coercive influence of one person on the other, arising from the common and mutually beneficial interactions between two humans (Nivison 1996; Pines 2002; Gassmann 2011). In short, de can be aptly explained as a particular, instantaneous and unique expression of the totality of the human way of life and action (or dao, in early Chinese terminology; Rosemont and Ames 2009). In the early Chinese tradition, there are also less human-centered understandings of dao and de, but, taken in the most general form, it is clear that in this more Confucian rendition of the terms, there is a significant thematic overlap with what would be considered moral concerns in the West.

This apparent overlap of the two terms - moral and daode - seemingly justifies and facilitates scholarly explorations of what Chinese, past and present, hold as a "moral issue" and what Chinese consider as "immoral actions". Such a formulation of the question poses a problem. Namely, specifically the English term from a Western cultural background is taken as a reference point in the subsequent cross-cultural discussions, and almost never the opposite is true (Shun 2009). As a result, an existence of a universal moral domain or moral cognition as existing separately from conventional or aesthetical normative domains is often taken for granted. Then, the non-Western cultures, at best, are forced to answer "Procrustean 
questions" that vex people with a Western worldview, but cannot necessarily be adequately expressed in non-Western traditional and modern languages (Rosemont 1988; Goldin 2005). This is not to say that non-Western intellectual traditions have never in any way or form inquired or given answers to what we in the West call moral questions. We suggest that, for example, in the Chinese intellectual tradition, we can find many relevant deliberations that touch upon important aspects of what would be understood as moral sensibilities in the Western sense. However, it seems that the Chinese start their questions and discussions from a set of normative categories that are significantly different from the Western ones.

\section{Daode 道德, wenming 文明, and $l i$ 禮}

A different approach would require starting from the Chinese concept daode, allowing that it could possibly be a unique Chinese way to categorize norms (Rosemont 1976; Buchtel et al. 2015). Accepting daode as a unique normative domain would also require to restrain from a critically unreflected intention to fit it into the allegedly universal sphere of moral norms. In contemporary academia, one of the most widespread ways in which moral psychologists and moral philosophers writing in English elucidate the concept moral is by contrasting it with the concept of conventional (Turiel 1983). Within this conventional domain one can find norms of etiquette, as well as other forms of "cultured", "civilized" behavior. If the terms moral and daode have the same meaning, we should see a similar moral / conventional contrast in Chinese as well. However, once we start the analysis of daode as Chinese concept within the Chinese cultural environment and intellectual tradition, we immediately see that various important terms that belong to the concept cluster surrounding the term wenming 文 明 (culture) are also close affiliates to the concept daode. Namely, for the Confucian tradition, the $d a o$ and $d e$ were foremost the terms to analyze and describe human actions, and 
conditions, and already in the early Confucian texts dating as early as 3rd century BCE, the dao and de were closely associated with refined, cultured, and civilized (wen 文) life and actions, which were subsumed within the notion of $l i$ 禮 (see Liji: Quli I.8, Xunzi 1.12). In such a cultural context, it is difficult to expect a strict separation or even an intention to separate conventional (cultural) and moral norms.

The term $l i$ is usually translated as ritual, but it also means ceremonies, rites, customs, proprieties, etiquette, and also morals. It is one of the most fundamental concepts in early Chinese intellectual tradition, denoting the whole set of culturally agreed, formalized ways of personal and social interactions that has to be personalized in each particular interpersonal encounter. The important thing to note here is that there is a "moral" meaning that is present in the term $l i$, but it seems to be inseparable in early texts from all the other connotations that are closer to the contemporary Western idea of the domain of "conventional", including aesthetical norms of decorum and cultural norms of civilized behavior (Rosemont 1976). Even more importantly, suggestions are made that for early Chinese, $l i$ is not merely a social and secondary attribute of human communities, but is also a fundamental quality in a sense of "human-building conventions" that constitute human beings and make human life possible (Neville 2008, 29).

\section{Do daode 道德 and wenming 文明 overlap?}

Taking these traditional Confucian views into account, and given the continuing cultural and social influences of Confucian worldview on contemporary Chinese society, one should expect that conventional cultural norms and regulations, or civilized behavior (wenhua 文化 / wenming 文明 in contemporary Chinese) for the everyday Chinese speaker would naturally 
be included into the daode normative domain. Thus, when translated in a standard way into English, these norms would be conceptualized as moral norms. To the extent that in the traditional Chinese view $l i$ is understood to be definitive of the very human existence itself, one can also expect that questions concerning the accordance to conventional cultural norms and civilized behavior will be met by Chinese with a very strong conviction and emotional response, similar to one that is observed in Western respondents reacting to moral transgressions (see, for instance, research on moral / conventional task: Nucci 2001; Smetana 1993; Tisak 1995; Turiel 1983).

Claims to these effects are not limited to theoretical literature, though. Emma Buchtel and her colleagues in a recent empirical paper (2015) note that the "Chinese lay concept of "immorality" is more applicable to spitting on the street than killing people" (p. 1386). In describing one of their studies they write: "although $70 \%$ of Beijing participants called to spit on the public street "immoral" (11\% of Westerners), only $42 \%$ of Beijing participants called to kill a person "immoral" (81\% of Westerners)" (p. 1388). As further noted by these authors, "Results suggest that Chinese were more likely to use the word immoral for behaviors that were uncivilized, rather than exceptionally harmful, whereas Westerners were more likely to link immorality tightly to harm" (p. 1382).

Such results seem to suggest that $b u$ daode is a significantly different concept from English immoral, which presents us with at least two theoretical options. Either some other expression of Mandarin Chinese translates "immoral" or no exact translation is available and Mandarin Chinese presents an alternative division of the normative space. In this paper, building on the pioneering work of Buchtel and her colleagues, we will discuss new empirical data bearing on these questions. 


\section{Study 1: Free-listing}

In this study, we set out to collect prototypically immoral and prototypically uncultured behaviors, as understood by American, Mainland Chinese, and Lithuanian participants. In order to explore the typicality of transgressions, we have adopted one of the traditional methods in cognitive anthropology - free-listing. It is especially useful in that it allows researchers to familiarize themselves with the concepts shared and used by the respondents (see de Munck, 2009, Ch. 3). Free-listing allows one to describe the conceptual domain from an emic perspective, as it is used within a particular cultural group. It is a snapshot of the most salient features of the concept under investigation. Emic data can be useful in themselves and they also can be quantified and structured into etic (that is, formulated in the language used by the social scientists) categories.

\section{Method}

Participants. American, Chinese, and Lithuanian participants were recruited online to complete a short questionnaire $(\mathrm{N}=356$; After removing 3 participants from outside the US and 4 incomplete questionnaires: $\mathrm{N}=349$; Age range=17-63; Median age=24; Mean age=28; Male=130; Female=229). ${ }^{1}$ US participants were recruited via Mechanical Turk for a small fee. Chinese and Lithuanian participants were recruited by distributing the web link to an online questionnaire among students and staff of universities in the respective countries.

\footnotetext{
${ }^{1}$ Participant characteristics by country: USA (N=114; After removing 3 from outside US: $\mathrm{N}=111$; Age range $=20-63$; Median age $=30$; Mean age $=34$; Male=55; Female $=65$ ); Mainland China $(\mathrm{N}=122$; Age range $=17-61$; Median age $=22$; Mean age $=24$; Male=34; Female=88); Lithuania (N=121; After removing 4 incomplete answers: $N=117$; Age range=18-63; Median age $=22$; Mean age $=29 ;$ Male $=41 ;$ Female $=76$ ).
} 
Materials and procedures. Participants were given the following prompt (two groups: one was asked about immoral, the other about uncultured behaviors):

The aim of this study is to learn which actions or behaviors are considered immoral [uncultured]. Please provide a list of actions and behaviors which, in your opinion, are immoral [uncultured]. Please list at least five examples. There are no correct answers, we are just interested in your opinion.

The following term-pairs (Table 1) were used in the English, Mandarin Chinese, and Lithuanian versions. Please refer to Appendix 1 for precise formulations in all three languages. ${ }^{2}$

[Insert Table 1 approximately here]

Coding. Participants provided lists which were mostly composed of lists of simple verbs or nouns referring to particular behaviors. However, some terms were either synonymous or superfluously formulated, therefore we ran through the lists to reduce the number of terms by unifying synonyms, where appropriate, changing from singular to plural and vice versa, and checking for typos. Lithuanian and English lists were coded each by two of the authors and then any remaining differences were resolved through discussion among all three authors. Mandarin Chinese lists were coded by one author and any remaining questions were settled by discussions with native speakers of Mandarin Chinese.

\footnotetext{
${ }^{2}$ Note, in this paper we will sometimes refer, for ease of exposition, to Chinese or Lithuanian terms by using English terms. This, however, should not be taken as suggesting that, for example, bu daode is an exact translation of immoral. In fact, we will argue, on the basis of our results, that the English term immoral and Chinese term bu daode differ in very crucial respects.
} 


\section{Results}

\section{Free-listing frequencies}

The numbers of different terms resulting from data analysis with the software program FLAME (Pennec et al., 2012), which builds upon the now classic program for free-list analysis ANTHROPAC (Borgatti, 1996), are reported in Table 2.

[Insert Table 2 approximately here]

The most frequently used terms and their frequencies are reported in Table 3 and Table 4.

[Insert Tables 3 and 4 approximately here]

The results on prototypically immoral transgressions seem to accord with recently reported results, employing similar methodologies. US results for immoral are largely in accordance with results by Gray et al. (2015), Mainland Chinese results for bu daode are in accordance with results reported by Buchtel et al. (2015), while Lithuanian results accord well with a study reported by Berniūnas and Dranseika (2017). Free-listing studies on uncultured, bu wenming, nekultüringa were not previously done, to the best of our knowledge.

At first glance, the following trends seem to emerge in the data. In Mandarin Chinese, lists of bu daode and bu wenming behaviors seem to be very similar (Table 5): the top 3 items overlap ("being loud", "littering", and "spitting”), 7 items overlap in the top 10, and 12 items make it into both top 20 lists. Numbers are much smaller for Lithuanian, and, especially, English lists. Only one item ("stealing") made it into both lists of the top 10 USA immoral and uncultured behaviors. Within the top 20 lists, one more item is common - "fighting / hitting". This suggests that there is a much more pronounced difference between 
prototypically immoral and prototypically uncultured behaviors in the USA than between prototypically bu daode and prototypically bu wenming behaviors in Mainland China, with Lithuanian results falling closer to American than Chinese results. This seems partly in conformity with results reported by Buchtel et al. (2015), who report that in Mandarin Chinese, an especially strong link exists between "immoral" and "uncivilized".

[Insert Table 5 approximately here]

Comparison between groups

In order to look at these data in a more quantitative manner, we put together the top 10 most frequently mentioned items from all six lists (3 languages; 2 conditions (immoral and uncultured) in each) and, after removing duplicates, a list of 39 items was compiled (see Appendix 2). Then we checked the percentage of participants who mentioned any particular item in their lists as well as differences between the lists (see Appendix 3). For example, in an immoral condition, stealing was mentioned by $78.33 \%$ of American participants, while in an uncultured condition - by $12.24 \%$ of American participants. Then we treated the difference between percentages as a measure of difference between the lists, thus resulting in a numerical value of 66.09 as a measure of difference between the American immoral and uncultured lists for the term "stealing". Differences between USA and Mainland China, and between Lithuania and Mainland China were statistically significant. For example, differences between frequencies of items in immoral and uncultured lists were larger than differences between frequencies of items in bu daode and bu wenming lists). A MannWhitney $U$ test indicated that differences between conditions in the USA sample $(\mathrm{Mdn}=6.67)$ were larger than differences between conditions in the Mandarin Chinese sample $(\mathrm{Mdn}=1.75), \mathrm{U}=460.5, p=.003, r_{r b}=.39$. Similarly, a Mann-Whitney $\mathrm{U}$ test indicated that 
differences between conditions in the Lithuanian sample (Mdn=8.93) were larger than differences between conditions in the Mandarin Chinese sample ( $\mathrm{Mdn}=1.75), \mathrm{U}=395.5, p<$ $.001, r_{r b}=.48$. No difference was observed between USA and Lithuania. A Mann-Whitney U test did not indicate that differences between conditions in the USA sample $(\mathrm{Mdn}=6.67)$ were either larger or smaller than differences between conditions in the Lithuanian sample $(\mathrm{Mdn}=8.93), \mathrm{U}=733.5, p=.787, r_{r b}=.04$.

\section{Discussion}

Our data seem to support the claim by Buchtel et al. (2015) that the Chinese tend to think about "immoral" and "uncivilized / uncultured" as tightly interconnected concepts, whereas the Westerners tend to conceive of these two categories as rather different, and perhaps opposing, as in a moral/conventional distinction of the Turiel tradition in moral psychology (1983). The results are also in agreement with the theoretical position expressed by Rosemont (1976).

It may also be worth noting that Kupperman (2002), writing on why Western philosophers should read Kongzi, stated:

"The characteristic preoccupations of contemporary Anglo-American ethical philosophy, especially, begin with moral or social choice. Such choices in their nature involve a great deal at stake, and for most people will seem to occur infrequently. This focus leads to [..] 'big moment ethics,' one of whose appealing features is that (by its emphasis on major choices at ethical crossroads) it in effect treats almost all of life apart from the big moments as an ethical free-play zone, in which one can do whatever one likes." (p. 40). 
This characterization seems to also fit the ordinary Western concept of morality emerging from our data. Prototypically, immoral behaviors for American participants can be characterized as being more extreme and less likely to be encountered in daily activities, whereas prototypically bu daode behaviors for Mainland Chinese participants, on the contrary, were quite mundane and likely to be encountered in daily activities. While killing/murder was the most frequently mentioned item in the USA sample (mentioned by $82 \%$ of participants) and made it to the top 3 in the Lithuanian sample (38\%), only one Chinese participant mentioned it. Furthermore, the most frequently mentioned items in the Chinese list (being loud, littering, spitting, cutting in line) were mentioned very seldom, if at all, by Lithuanians and Americans.

\section{Study 2: Bu lunli 不倫理 and $\boldsymbol{b u}$ hefa 不合法}

Given the fact that prototypically immoral behaviors were very different from prototypically bu daode behaviors, we decided to explore two other Chinese terms to see whether they will allow us to identify terms whose prototypical instances are more similar to the American immoral behaviors. The terms we chose are bu lunli 不倫理 and bu hefa 不合法. For these two additional studies, we used the same method and data coding procedures as the previous study. The only difference was that the terms inserted in the probes were different. Please refer to Appendix 1 for precise formulations.

\section{Study 2a: Bu lunli 不倫理}

The reason for choosing bu lunli is that it is yet another Chinese term that could potentially be equivalent to the field of immorality as it is understood in the West. In contemporary Chinese academia, the terms daode and lunli were even taken to roughly correspond to the 
distinction between morality and ethics, which is a well-established distinction in Western philosophical literature (for a short overview see Gao 2005, 44-58). In this case, daode is taken as a more subjective aspect and taken as a translation of morality. Lunli is taken to translate as the English term ethics, understood as a systematic development and grounding of subjective moral intuitions and convictions, as a theory of morality (Gao 2005, 44). Lunli, too, has a long history of usage in early Chinese texts and both Chinese characters have been important terms in the Chinese tradition. Lun 倫 in early Chinese texts means "class of things" or "order of things", but was primarily used as meaning "interpersonal human relations", or - in more processual reading by Roger Ames - as "the living of one's roles and relations" (Ames 2011, 97). This term was also widely used in a compound wulun 五倫 which in Confucian tradition means “five cardinal human relations". $L i$ 理, another important and rich term in Chinese intellectual tradition, here simply means "structure, pattern". Both Chinese characters compose a single term lunli meaning "patterned human relations"

The study participants were recruited online via SoJump.com for a small fee $(\mathrm{N}=52$; Age range $=20-45 ;$ Median age $=29.5$; Mean age $=30 ;$ Male=25; Female=27). The most frequently mentioned items are listed in Table 6.

[Insert Table 6 approximately here]

There are three items that overlap between the top 10 lists of bu daode and bu lunli behaviors: spitting, stealing, and insulting. However, looking at the whole lists, there seems to be a rather clear difference among them in a sense that the prototypical bu daode (as well as bu wenming) behaviors are more often issues of public propriety, where there is no clear individual victim (e.g. being loud, littering, spitting), while the prototypical bu lunli 
behaviors are more saliently those that have identifiable victims, often in the family context, such as unfilial conduct and adultery. This seems to be consistent with the traditional Chinese usages of lunli as explained above. However, overlap among the top 10 lists of American immoral and Mandarin Chinese bu lunli behaviors is very limited - there are only two items in common: stealing and adultery.

\section{Study 2b: Bu hefa 不合法}

The notion hefa 合法 in contemporary Chinese means "legal, lawful, legitimate". It is clearly a legal notion, associated with formalized legal norms, which are supervised by the state authority. The second character in this binomial, i.e. $f a$ 法, in early Chinese intellectual tradition meant "norm, law, standard, regulation", while the first one, he 合, simply means "to suit, to agree with". $F a$ 法 was one of the central terms in the early Chinese school of thought fajia 法家, or the Legalists. This school was one of the main intellectual rivals of Confucians in suggesting the best ways of structuring people's lives, society, and the state. In this rivalry $f a$, as one of the main pillars of Legalist thought, was mainly contrasted with $l i$ 禮 , or the ritual, which was one of the pillars of Confucian thought. $F a$ was to be formally established and enforced by the state through the means of punishment. $L i$, on the other hand, was understood more as a communal means of interaction, that has to be personally internalized through education. The adherence to the $l i$ norms was to be induced by the personal example of state and communal leaders (see, for example, Lunyu 2.3).

For this study, participants were also recruited online via SoJump.com for a small fee $(\mathrm{N}=58$; Age range $=20-66 ;$ Median age $=31 ;$ Mean age=34; Male=30; Female=28). The most frequently mentioned items are listed in Table 6 . There are three items that overlap between the top 10 lists of bu daode and bu hefa behaviors: stealing, damaging public property, and 
not observing traffic rules. However, there seems to be a rather clear difference between the two lists in a sense that the prototypical bu daode (as well as bu wenming) behaviors are more often issues of public propriety, while the prototypical bu hefa behaviors are those that have clear legalistic implications. Four items overlap between the top 10 lists of USA immoral and Mandarin Chinese bu hefa behaviors: killing / murder, stealing, cheating, and raping. Furthermore, all four items appear high on the lists: within the top 5 items in both lists. One interpretation of these results is that there is an accidental connection here based on the fact that legal regulations also cover the most extreme moral transgressions. However, there can be an alternative interpretation, suggesting that there is a close connection between law and modern Western notions of morality, as suggested by Anscombe (1958). Under this legalistic reading, there indeed would be some affinity between morality and hefa.

\section{General discussion}

These differences between prototypically bu daode, bu wenming, bu lunli, and bu hefa behaviors seem to hint at different aspects of why behaviors are valued negatively: bu daode and $b u$ wenming seem to be especially focused on public propriety, bu lunli- on interpersonal relationships within a family context or relations with identifiable others, while $b u$ hefa seems to refer to legal prohibitions. All three aspects can be recognized within the English meaning of morality, but these preliminary results seem to suggest that the Chinese have more explicit and more clearly delineated normative domains focused on these aspects.

One of the reviewers encouraged us to explain why we should interpret these results as relevant not only to lexical semantics - that is, the study of the meanings of words in human languages - but also to conceptual distinctions in Psychology and Philosophy. That is why we think that our empirical methods could be suitable for the latter task. 
On the one hand, we would be happy to limit ourselves in this paper to a more modest claim that - as a matter of meaning of words - daode does not translate as morality. We would be happy if this article serves as a warning and a reminder to academic translators of Western and Chinese literature, and Chinese-speaking students of Western tradition, as well as English-speaking students of the Chinese tradition.

On the other hand, we would like to provide three arguments why we think that the present work can be relevant to cross-cultural Moral Psychology.

First, free-listing is a classic cognitive task used routinely to recover the prototypical structure of how people cognitively represent various concepts and categories (see, for instance, the classic work by Eleanor Rosch on the internal prototypical structures of ordinary object concepts via lists of attributes and characteristics of different kinds of ordinary everyday objects; Rosch and Mervis, 1975). There is a long tradition of using this method as a cognitive measure in psycholinguistics and cognitive anthropology (de Munck, 2009). Indeed, the free-listing method has been employed to study a wide array of cultural domains, where "[a] domain may be defined as an organized set of words, concepts, or sentences, all on the same level of contrast, that jointly refer to a single conceptual sphere" (Weller \& Romney, 1988). Thus, we are reluctant to agree that the method is suitable only to the study of the meanings of words.

Second, the results of the present study are in line with results obtained using other and perhaps less controversial methods. One reviewer helpfully pointed out that it would be a good idea to use different and more experimental methods to study how people conceptualize morality. By giving them scenarios of various kinds of transgressions (and by avoiding any usage of the English immoral or the Chinese bu daode, we would be in a better position to grasp the conceptual interconnection between the moral and conventional domains. As a 
matter of fact, in a different study (Berniūnas, Dranseika, and Silius, under review) we did exactly that and found that, indeed, Chinese tend to moralize - in a sense of "moral signature" (Berniūnas, Dranseika, and Sousa, 2016)) - typically conventional (as usually understood in the Moral Psychology literature) transgressions more often than the American participants. Edouard Machery also refers to an ongoing research program (see Machery 2012 for a description and Levine et al. (unpublished manuscript) for the first results) that aims to uncover differences in how people categorize norms and found that "Americans draw a sharp distinction between moral and nonmoral norms and also distinguish different kinds of moral and nonmoral norms. In contrast, Indian participants do not seem to draw distinction between moral and nonmoral norms, suggesting that the moral domain may not be a universal." (Machery 2018: 263).

Third, Machery provides an argument that aims to show the relevance of such linguistic data to the study of cognitive universals. Referring to the work of Anna Wierzbicka, who claims that, in contrast to such deontic modals as "ought" and such normative predicates as "right" or "wrong", some languages do not have a word for "morality" and thus do not lexicalize the distinction between morally good and morally bad (Wierzbicka 2001; 2007). Machery writes: "If the moral domain were a fundamental feature of human cognition, we would expect the distinction between moral and nonmoral norms to be lexicalized in every language, as are deontic modals and the distinction between good and bad" (2018: 262).

In the light of these arguments, we have hope that our paper will make a modest contribution to the psychological understanding of moral cognition.

\section{Conclusion}


How should we approach the question of whether bu daode and immorality is the same concept? One motive to resist their identification is the following: concepts do not function in isolation, they come in larger conceptual schemes and the business of translation should preserve these relations between concepts. If we believe that the Western concept of immorality is defined in contraposition to things that are matters of etiquette or conventional norms (which is very much consistent with results obtained from the American and Lithuanian samples) and thus tied to a more or less tangible moral / conventional distinction, then our results indicate that in the case of Mandarin Chinese, we are dealing with a different conceptual structure. It seems that the prototypically bu daode and bu wenming behaviors largely overlap, thus making this pair of terms not suitable to express a conceptual contrast that we see in the classic moral / conventional distinction, so central to contemporary Moral Psychology (e.g. Turiel 1983; Nucci 2001) and Moral Philosophy (e.g. Nichols, 2004; Joyce, 2006). The current study seems to support an emerging skepticism about the rigidity and centrality of moral / conventional distinctions in folk moral cognition (see also Levine et al., unpublished manuscript; Machery and Mallon, 2010; Sachdeva, Singh, and Medin, 2011; Sripada and Stich, 2006). Indeed, there is a kind of functional lack of equivalence between these term pairs in English and Mandarin Chinese, and one ought to keep this in mind while conducting cross-cultural investigations of moral psychology, as well as when translating these terms between the languages.

\section{Acknowledgments}

This research was funded by a grant (No. MIP-15506) from the Research Council of Lithuania. An earlier version of this paper was presented at conferences at University of Vilnius, Tartu University, Kaunas University of Technology, and Osnabrück University, and a workshop at University of Iceland. We wish to thank the audiences at these events for suggestions on how to improve the paper. We also thank two anonymous reviewers for this 
journal for their valuable comments, Agnè Veisaitė for help with coding data, and Phyllis Zych-Budka and Vincent Giedraitis for language editing.

\section{References}

Ames, R. T. (2011). Confucian role ethics: A vocabulary, Hong Kong: Chinese University Press.

Ames, R. T., \& Rosemont, H. (1998). The Analects of Confucius: A philosophical translation, New York: Ballantine Books.

Anscombe, G. E. M. (1958). Modern moral philosophy. Philosophy, 33(124), 1-19.

Borgatti, S. (1996). ANTHROPAC 4.0. Natick, MA: Analytic Technologies.

Berniūnas, R., \& Dranseika, V. (2017). Thou shalt not kill, steal, and lie: A preliminary study on cognitively salient moral transgressions among Lithuanians. Žmogus ir žodis, 19 (4), 94-107.

Berniūnas, R., Dranseika, V., Silius, V. (under review). Moralization East and West: Moralizing different transgressions among Chinese, Americans and Lithuanians.

Berniūnas, R., Sousa, P., Dranseika, V. (2016). Are there different moral domains: evidence from Mongolia. Asian journal of social psychology, 19, 275-282.

Buchtel, E. E., Guan, Y., Peng, Q., Su, Y., Sang, B., Chen, S. X., \& Bond, M. H. (2015). Immorality East and West. Are immoral behaviors especially harmful, or especially uncivilized? Personality and Social Psychology Bulletin, 41(10), 1382-1394.

De Munck, V. C. (2009). Research design and methods for studying cultures. Walnut Creek, CA: AltaMira.

Gao Guoxi 高国希 (2005). Daode zhexue 道德哲学 [Moral philosophy], Shanghai: Fudan daxue chubanshe.

Gassmann, R.H. 2011. Coming to terms with dé 德: the deconstruction of "virtue" and an exercise in ccientific morality. In R.A.H. King and Dennis Schilling (eds.) How should one live? Comparing ethics in Ancient China and Greco-Roman Antiquity, Berlin, Boston: Walter de Gruyter: 92-125.

Goldin, P. R. (2005). After Confucius: Studies in early Chinese philosophy, Honolulu: University of Hawaii Press.

Graham, J., Nosek, B. A., Haidt, J., Iyer, R., Koleva, S., \& Ditto, P. H. (2011). Mapping the moral domain. Journal of personality and social psychology, 101(2), 366-385. 
Joyce, R. (2006). The evolution of morality. Cambridge, MA: MIT Press.

Kupperman, J. J. (2002). Naturalness revisited: Why Western philosophers should study Confucius. In Bryan W. Van Norden (Ed.), Confucius and the Analects: New essays, (pp. 39-52). Oxford: Oxford University Press.

Levine, S., Rottman, J., Davis, T., O'Neill, E., Stich, S., \& Machery E. (unpublished manuscript). Religion's Impact on Conceptions of the Moral Domain.

Liji 禮記 [The Book of Rites], in Chinese Texts Project. http://ctext.org/liji/qu-li-i\#n9485. Accessed 15 Aug 2016.

Machery, E. (2012). Delineating the moral domain. Baltic international yearbook of cognition, logic and communication, 7(1), 6.

Machery, E. (2018). Morality: A historical invention. In K. Gray \& J. Graham (Eds.), The atlas of moral psychology. New York: The Guilford Press: 259-265.

Machery, E., \& Mallon, R. (2010). Evolution of morality. In J. M. Doris (Ed.), The moral psychology handbook (pp. 3-46). New York, NY: Oxford University Press.

Neville, R. C. (2008). Ritual and deference: Extending Chinese philosophy in a comparative context. New York: SUNY Press.

Nichols, S. (2004). Sentimental rules. New York: Oxford University Press.

Nivison, D. S. 1996. The ways of Confucianism: Investigations in Chinese philosophy, edited with an introduction by Bryan W. Van Norden. Chicago and La Salle, Illinois: Open Court.

Nucci, L. P. (2001). Education in the moral domain. Cambridge: Cambridge University Press.

Pennec, F., Wencelius, J., Garine, E., Raimond, C., \& Bohbot, H. (2012). FLAME 1.1. Paris: CNRS.

Pines, Y. 2002. Foundations of Confucian thought: Intellectual life in the Chunqiu period, 722-453 B.C.E., Honolulu: University of Hawai'i Press.

Rosemont, H. (1988). Against relativism. In James Larson and Eliot Deutsch (Eds.) Interpreting across boundaries: New essays in comparative philosophy, (pp. 36-70). Princeton: Princeton University Press.

Rosemont, H. (1976). Notes from a Confucian perspective: Which human acts are moral acts? International philosophical quarterly, 16(1), 49-61.

Rosemont, Jr., H., \& Ames R.T. 2009 (tr.). The Chinese classic of family reverence: A philosophical translation of the Xiaojing, Honolulu: University of Hawai'i Press. 
Rosch, E., \& Mervis, C. B. (1975). Family resemblances: Studies in the internal structure of categories. Cognitive psychology, 7, 573-605.

Sachdeva, S., Singh, P., and Medin, D. (2011). Culture and the quest for universal principles in moral reasoning. International journal of psychology, 46(3), 161-176.

Schein, C., and Gray, K. (2015). The unifying moral dyad: Liberals and conservatives share the same harm-based moral template. Personality and social psychology bulletin, 41(8), 1147-1163.

Shun, K. (2009). Studying Confucian and comparative ethics: methodological reflections, Journal of Chinese philosophy, 36(3), 455-478.

Smetana, J. (1993). Understanding of social rules. In M. Bennett (Ed.), The development of social cognition: The child as psychologist, (pp. 111-141). New York: Guilford Press.

Sripada, C., \& Stich, S. (2006). A Framework for the psychology of norms. In P. Carruthers, S. Laurence, \& S. Stich (Eds.), The innate mind, Volume 2: Culture and cognition, (pp. 280-301). Oxford University Press.

Xunzi 荀子, in Chinese Texts Project, accessed on-line (2016 08 15) http://ctext.org/xunzi/quan-xue\#n12253

Tisak, M. (1995). Domains of social reasoning and beyond. In R. Vasta (Ed.), Annals of child development (Vol. 11), (pp. 95-130). London: Jessica Kingsley.

Turiel, E. (1983). The development of social knowledge: Morality and convention. Cambridge, England: Cambridge University Press.

Weller, S. C., and A. K. Romney. 1988. Systematic data collection. Newbury Park, CA: Sage.

Wierzbicka, A. (2001). What did Jesus mean? Explaining the Sermon on the Mount and the Parables in simple and universal human concepts. New York: Oxford University Press.

Wierzbicka, A. (2007). Moral sense. Journal of social, evolutionary, and cultural psychology 1: 66-85. 
Tables

Table 1. Term pairs used in the study

\begin{tabular}{|c|c|c|}
\hline & Immoral & Uncultured \\
\hline Mandarin Chinese & 不道德 (bu daode) & 不文明 (bu wenming) \\
\hline English & Immoral & Uncultured \\
\hline Lithuanian & Amoralu & Nekultūringa \\
\hline
\end{tabular}


Table 2. Number of lists and cited items

\begin{tabular}{|c|c|c|c|c|c|}
\hline & Immoral & Uncultured & $\begin{array}{c}\text { Number of } \\
\text { lists }\end{array}$ & $\begin{array}{c}\text { Number of } \\
\text { cited items } \\
\text { (types) }\end{array}$ & $\begin{array}{c}\text { Number of } \\
\text { cited items } \\
\text { (tokens) }\end{array}$ \\
\hline \multirow{2}{*}{$\begin{array}{c}\text { Mandarin } \\
\text { Chinese }\end{array}$} & $\begin{array}{c}\text { 不道德 (bu } \\
\text { daode) }\end{array}$ & & 57 & 91 & 276 \\
\cline { 2 - 7 } & 不文明 (bu & 65 & 72 & 314 \\
\hline \multirow{2}{*}{ English } & wenming) & & 60 & 91 & 301 \\
\cline { 2 - 7 } & & Uncultured & 49 & 118 & 248 \\
\hline \multirow{2}{*}{ Lithuanian } & Amoralu & & 61 & 110 & 341 \\
\cline { 2 - 7 } & & Nekultūringa & 56 & 106 & 308 \\
\hline
\end{tabular}


Table 3. Most frequently mentioned immoral (bu daode, amoralu) behaviors. Numbers in brackets represent the number of participants in a condition. FREQ shows how many participants mentioned a given term. Percentages indicate the proportion of participants in the group who mentioned a given term in their lists.

\begin{tabular}{|c|c|c|c|c|c|c|c|c|}
\hline \multicolumn{3}{|c|}{ LITHUANIAN (61) } & \multicolumn{3}{|c|}{ AMERICAN (60) } & \multicolumn{3}{|c|}{ CHINESE (57) } \\
\hline ITEM & $\begin{array}{c}\text { FRE } \\
\mathbf{Q}\end{array}$ & $\%$ & ITEM & $\begin{array}{c}\text { FRE } \\
\mathbf{Q}\end{array}$ & $\%$ & ITEM & $\begin{array}{c}\text { FRE } \\
\mathbf{Q}\end{array}$ & $\%$ \\
\hline $\begin{array}{l}\text { meluoti } \\
\text { / lying }\end{array}$ & 28 & $\begin{array}{l}45.90 \\
\%\end{array}$ & killing / murder & 49 & $\begin{array}{c}81.67 \\
\%\end{array}$ & $\begin{array}{l}\text { 公共场合喧哗 } \\
\text { / being loud }\end{array}$ & 28 & $\begin{array}{c}49.12 \\
\%\end{array}$ \\
\hline $\begin{array}{l}\text { vogti } \\
\text { / stealing }\end{array}$ & 26 & $\begin{array}{c}42.62 \\
\%\end{array}$ & stealing & 47 & $\begin{array}{c}78.33 \\
\%\end{array}$ & $\begin{array}{l}\text { 乱扔垃圾_ } \\
\text { / littering }\end{array}$ & 27 & $\begin{array}{c}47.37 \\
\%\end{array}$ \\
\hline $\begin{array}{l}\text { žudyti } \\
\text { / killing/murder }\end{array}$ & 23 & $\begin{array}{c}37.70 \\
\%\end{array}$ & cheating & 25 & $\begin{array}{c}41.67 \\
\%\end{array}$ & $\begin{array}{l}\text { 随地吐痰 } \\
\text { / spitting }\end{array}$ & 24 & $\begin{array}{l}42.11 \\
\%\end{array}$ \\
\hline $\begin{array}{l}\text { smurtauti } \\
\text { / violence }\end{array}$ & 20 & $\begin{array}{c}32.79 \\
\%\end{array}$ & raping & 24 & $\begin{array}{c}40.00 \\
\%\end{array}$ & $\begin{array}{l}\text { 插队 } \\
\text { / cutting in line }\end{array}$ & 15 & $\begin{array}{c}26.32 \\
\%\end{array}$ \\
\hline $\begin{array}{l}\text { tyčiotis } \\
\text { / bullying }\end{array}$ & 18 & $\begin{array}{c}29.51 \\
\%\end{array}$ & lying & 20 & $\begin{array}{c}33.33 \\
\%\end{array}$ & $\begin{array}{l}\text { 欺骗 } \\
\text { / cheating }\end{array}$ & 14 & $\begin{array}{c}24.56 \\
\%\end{array}$ \\
\hline $\begin{array}{l}\text { išduoti } \\
\text { / betrayal }\end{array}$ & 11 & $\begin{array}{c}18.03 \\
\%\end{array}$ & animal abuse & 9 & $\begin{array}{l}15.00 \\
\%\end{array}$ & $\begin{array}{l}\text { 公共场合吸烟 } \\
\text { / smoking in public }\end{array}$ & 13 & $\begin{array}{l}22.81 \\
\%\end{array}$ \\
\hline $\begin{array}{l}\text { negerbti kitu } \\
\text { / disrespecting others }\end{array}$ & 10 & $\begin{array}{c}16.39 \\
\%\end{array}$ & adultery & 8 & $\begin{array}{c}13.33 \\
\%\end{array}$ & $\begin{array}{l}\text { 盗窃 } \\
\text { / stealing }\end{array}$ & 8 & $\begin{array}{c}14.04 \\
\%\end{array}$ \\
\hline $\begin{array}{l}\text { svetimauti } \\
\text { / adultery }\end{array}$ & 8 & $\begin{array}{c}13.11 \\
\%\end{array}$ & paedophilia & 8 & $\begin{array}{c}13.33 \\
\%\end{array}$ & $\begin{array}{l}\text { 辱骂他人 } \\
\text { / insulting }\end{array}$ & 8 & $\begin{array}{c}14.04 \\
\%\end{array}$ \\
\hline $\begin{array}{l}\text { kankinti gyvūnus } \\
\text { / animal abuse }\end{array}$ & 8 & $\begin{array}{c}13.11 \\
\%\end{array}$ & harming others & 7 & $\begin{array}{c}11.67 \\
\%\end{array}$ & $\begin{array}{l}\text { 破坏公物 } \\
\text { / damaging public } \\
\text { property }\end{array}$ & 6 & $\begin{array}{c}10.53 \\
\%\end{array}$ \\
\hline $\begin{array}{l}\text { apkalbinèti } \\
\text { / slandering }\end{array}$ & 7 & $\begin{array}{l}11.48 \\
\%\end{array}$ & violence & 7 & $\begin{array}{c}11.67 \\
\%\end{array}$ & $\begin{array}{l}\text { 不遵守交通规则 } \\
\text { / not observing traffic } \\
\text { rules }\end{array}$ & 6 & $\begin{array}{c}10.53 \\
\%\end{array}$ \\
\hline $\begin{array}{l}\text { išnaudoti } \\
\text { / exploiting }\end{array}$ & 7 & $\begin{array}{c}11.48 \\
\%\end{array}$ & fighting / hitting & 6 & $\begin{array}{c}10.00 \\
\%\end{array}$ & $\begin{array}{l}\text { 不让座 } \\
\text { / not giving seat }\end{array}$ & 5 & $8.77 \%$ \\
\hline $\begin{array}{l}\text { sukčiauti } \\
\text { / cheating }\end{array}$ & 7 & $\begin{array}{c}11.48 \\
\%\end{array}$ & child abuse & 6 & $\begin{array}{c}10.00 \\
\%\end{array}$ & $\begin{array}{l}\text { 随地大小便/ urinating } \\
\text { or defecating publicly }\end{array}$ & 5 & $8.77 \%$ \\
\hline $\begin{array}{l}\text { girtauti } \\
\text { / alcohol abuse }\end{array}$ & 6 & $9.84 \%$ & discriminating & 4 & $\begin{array}{c}6.67 \\
\%\end{array}$ & $\begin{array}{l}\text { 打架/打人 } \\
\text { / fighting/hitting }\end{array}$ & 5 & $8.77 \%$ \\
\hline $\begin{array}{l}\text { vengti atsakomybès } \\
\text { / avoiding responsibility }\end{array}$ & 6 & $9.84 \%$ & racism & 4 & $\begin{array}{c}6.67 \\
\%\end{array}$ & $\begin{array}{l}\text { 不赡养父母 } \\
\text { / not providing for } \\
\text { parents }\end{array}$ & 4 & $7.02 \%$ \\
\hline $\begin{array}{l}\text { veidmainiauti } \\
\text { / hypocrisy }\end{array}$ & 5 & $8.20 \%$ & exploiting & 4 & $\begin{array}{c}6.67 \\
\%\end{array}$ & $\begin{array}{l}\text { 破坏花草 } \\
\text { / damaging lawn }\end{array}$ & 4 & $7.02 \%$ \\
\hline
\end{tabular}




\begin{tabular}{|l|c|c|l|l|l|l|l|l|}
\hline $\begin{array}{l}\text { negerbti tėų } \\
\text { / disrespecting parents }\end{array}$ & 5 & $8.20 \%$ & $\begin{array}{l}\text { disrespecting } \\
\text { others }\end{array}$ & 3 & $\begin{array}{l}5.00 \\
\%\end{array}$ & $\begin{array}{l}\text { 背后议论 } \\
/ \text { slandering }\end{array}$ & 3 & $5.26 \%$ \\
\hline $\begin{array}{l}\text { nepadèti } \\
\text { / not helping }\end{array}$ & 5 & $8.20 \%$ & torturing & 3 & $\begin{array}{c}5.00 \\
\%\end{array}$ & $\begin{array}{l}\text { 欺负 } \\
/ \text { bullying }\end{array}$ & $3.26 \%$ \\
\hline $\begin{array}{l}\text { ignoruoti kitus } \\
\text { /ignoring others }\end{array}$ & 4 & $6.56 \%$ & incest & 3 & $\begin{array}{c}5.00 \\
\%\end{array}$ & $\begin{array}{l}\text { 涂鸦 } \\
/ \text { graffiti }\end{array}$ & $5.26 \%$ \\
\hline $\begin{array}{l}\text { diskriminuoti } \\
\text { / discrimination }\end{array}$ & 4 & $6.56 \%$ & $\begin{array}{l}\text { damaging } \\
\text { environment }\end{array}$ & 3 & $\begin{array}{c}5.00 \\
\%\end{array}$ & $\begin{array}{l}\text { 损人利己 } \\
/ \text { being selfish }\end{array}$ & 3 & $5.26 \%$ \\
\hline $\begin{array}{l}\text { elgtis savanaudiškai } \\
\text { / being selfish }\end{array}$ & 4 & $6.56 \%$ & sodomy & 2 & $\begin{array}{c}3.33 \\
\%\end{array}$ & 道德绑架/ moralizing & 3 & $5.26 \%$ \\
\hline
\end{tabular}


Table 4. Most frequently mentioned uncultured (bu wenming, nekultūringa) behaviors.

Numbers in brackets represent the number of participants in a condition. FREQ shows how many participants mentioned a given term. Percentages indicate the proportion of participants in the group who mentioned a given term in their lists.

\begin{tabular}{|c|c|c|c|c|c|c|c|c|}
\hline \multicolumn{3}{|c|}{ LITHUANIAN (56) } & \multicolumn{3}{|c|}{ AMERICAN (69) } & \multicolumn{3}{|c|}{ CHINESE (45) } \\
\hline ITEM & $\begin{array}{c}\text { FRE } \\
\mathbf{Q}\end{array}$ & $\%$ & ITEM & $\begin{array}{c}\text { FRE } \\
\mathbf{Q}\end{array}$ & $\%$ & ITEM & $\begin{array}{c}\text { FRE } \\
\mathbf{Q}\end{array}$ & $\%$ \\
\hline $\begin{array}{l}\text { keiktis } \\
\text { / swearing }\end{array}$ & 27 & $\begin{array}{c}48.21 \\
\%\end{array}$ & swearing & 13 & $\begin{array}{c}26.53 \\
\%\end{array}$ & $\begin{array}{l}\text { 随地吐痰 } \\
\text { / spitting }\end{array}$ & 44 & $\begin{array}{c}67.69 \\
\%\end{array}$ \\
\hline $\begin{array}{l}\text { spjaudytis } \\
\text { / spitting }\end{array}$ & 22 & $\begin{array}{c}39.29 \\
\%\end{array}$ & farting & 13 & $\begin{array}{c}26.53 \\
\%\end{array}$ & $\begin{array}{l}\text { 乱扔垃圾 } \\
\text { / littering }\end{array}$ & 44 & $\begin{array}{c}67.69 \\
\%\end{array}$ \\
\hline $\begin{array}{l}\text { triuksmauti } \\
\text { / being loud }\end{array}$ & 17 & $\begin{array}{c}30.36 \\
\%\end{array}$ & picking nose & 12 & $\begin{array}{c}24.49 \\
\%\end{array}$ & $\begin{array}{l}\text { 公共场合喧哗 } \\
\text { / being loud }\end{array}$ & 38 & $\begin{array}{c}58.46 \\
\%\end{array}$ \\
\hline $\begin{array}{l}\text { siukslinti } \\
\text { / littering }\end{array}$ & 17 & $\begin{array}{c}30.36 \\
\%\end{array}$ & burping & 11 & $\begin{array}{c}22.45 \\
\%\end{array}$ & $\begin{array}{l}\text { 公共场合吸烟 } \\
\text { / smoking in public }\end{array}$ & 18 & $\begin{array}{c}27.69 \\
\%\end{array}$ \\
\hline $\begin{array}{l}\text { negerbti kitu } \\
\text { / disrespecting others }\end{array}$ & 10 & $\begin{array}{c}17.86 \\
\%\end{array}$ & being loud & 11 & $\begin{array}{c}22.45 \\
\%\end{array}$ & $\begin{array}{l}\text { 插队 } \\
\text { / cutting in line }\end{array}$ & 18 & $\begin{array}{c}27.69 \\
\%\end{array}$ \\
\hline $\begin{array}{l}\text { tyciotis } \\
\text { / bullying }\end{array}$ & 9 & $\begin{array}{c}16.07 \\
\%\end{array}$ & spitting & 7 & $\begin{array}{c}14.29 \\
\%\end{array}$ & $\begin{array}{l}\text { 说脏话 } \\
\text { / swearing }\end{array}$ & 16 & $\begin{array}{c}24.62 \\
\%\end{array}$ \\
\hline $\begin{array}{l}\text { apkalbineti } \\
\text { / slandering }\end{array}$ & 9 & $\begin{array}{c}16.07 \\
\%\end{array}$ & not washing & 7 & $\begin{array}{c}14.29 \\
\%\end{array}$ & $\begin{array}{l}\text { 不遵守交通规则 } \\
\text { / not observing traffic } \\
\text { rules }\end{array}$ & 10 & $\begin{array}{c}15.38 \\
\%\end{array}$ \\
\hline $\begin{array}{l}\text { negerbti vyresnių } \\
\text { / not respecting older people }\end{array}$ & 8 & $\begin{array}{c}14.29 \\
\%\end{array}$ & being rude & 6 & $\begin{array}{c}12.24 \\
\%\end{array}$ & $\begin{array}{l}\text { 辱骂他人 } \\
\text { / insulting }\end{array}$ & 10 & $\begin{array}{c}15.38 \\
\%\end{array}$ \\
\hline $\begin{array}{l}\text { ignoruoti kitus } \\
\text { / ignoring others }\end{array}$ & 7 & $\begin{array}{c}12.50 \\
\%\end{array}$ & stealing & 6 & $\begin{array}{c}12.24 \\
\%\end{array}$ & $\begin{array}{l}\text { 随地大小便 } \\
\text { / urinating or defecating } \\
\text { publicly }\end{array}$ & 7 & $\begin{array}{c}10.77 \\
\%\end{array}$ \\
\hline $\begin{array}{l}\text { girtauti } \\
\text { / alcohol abuse }\end{array}$ & 7 & $\begin{array}{c}12.50 \\
\%\end{array}$ & $\begin{array}{l}\text { chewing with } \\
\text { mouth open }\end{array}$ & 6 & $\begin{array}{c}12.24 \\
\%\end{array}$ & $\begin{array}{l}\text { 乱穿马路 } \\
\text { / jaywalking }\end{array}$ & 6 & $9.23 \%$ \\
\hline $\begin{array}{l}\text { pertraukineti kitus } \\
\text { / interrupting others }\end{array}$ & 7 & $\begin{array}{c}12.50 \\
\%\end{array}$ & bullying & 5 & $\begin{array}{c}10.20 \\
\%\end{array}$ & $\begin{array}{l}\text { 打架/打人 } \\
\text { / fighting/hitting }\end{array}$ & 6 & $9.23 \%$ \\
\hline $\begin{array}{l}\text { nesisveikinti } \\
\text { / not greeting others }\end{array}$ & 6 & $\begin{array}{c}10.71 \\
\%\end{array}$ & $\begin{array}{l}\text { eating with } \\
\text { hands }\end{array}$ & 5 & $\begin{array}{c}10.20 \\
\%\end{array}$ & $\begin{array}{l}\text { 涂鸦 } \\
\text { / graffiti }\end{array}$ & 6 & $9.23 \%$ \\
\hline $\begin{array}{l}\text { čepsèti } \\
\text { / chewing with mouth open }\end{array}$ & 6 & $\begin{array}{c}10.71 \\
\%\end{array}$ & poor manners & 5 & $\begin{array}{c}10.20 \\
\%\end{array}$ & $\begin{array}{l}\text { 在禁止吃饭的场合吃东 } \\
\text { 西 } \\
\text { / eating in unsuitable } \\
\text { places }\end{array}$ & 6 & $9.23 \%$ \\
\hline $\begin{array}{l}\text { grubiai bendrauti } \\
\text { / being rude }\end{array}$ & 6 & $\begin{array}{c}10.71 \\
\%\end{array}$ & $\begin{array}{l}\text { not holding } \\
\text { doors }\end{array}$ & 4 & $\begin{array}{c}8.16 \\
\%\end{array}$ & $\begin{array}{l}\text { 上则所不冲水 } \\
\text { / not flushing toilet }\end{array}$ & 5 & $7.69 \%$ \\
\hline
\end{tabular}




\begin{tabular}{|c|c|c|c|c|c|c|c|c|}
\hline $\begin{array}{l}\text { vèluoti } \\
\text { being late }\end{array}$ & 6 & $\begin{array}{c}10.71 \\
\%\end{array}$ & quarreling & 4 & $\begin{array}{c}8.16 \\
\%\end{array}$ & $\begin{array}{l}\text { 霸占座位 } \\
\text { / seizing seat }\end{array}$ & 4 & $6.15 \%$ \\
\hline $\begin{array}{l}\text { rūkyti viešumoje } \\
\text { / smoking in public }\end{array}$ & 6 & $\begin{array}{c}10.71 \\
\%\end{array}$ & fighting/hitting & 4 & $\begin{array}{c}8.16 \\
\%\end{array}$ & $\begin{array}{l}\text { 破坏公物 } \\
\text { / damaging public } \\
\text { property }\end{array}$ & 4 & $6.15 \%$ \\
\hline $\begin{array}{l}\text { lịsti be eilès } \\
\text { / cutting in line }\end{array}$ & 5 & $8.93 \%$ & not thanking & 3 & $\begin{array}{c}6.12 \\
\%\end{array}$ & $\begin{array}{l}\text { 不讲究卫生 } \\
\text { / poor sanitation }\end{array}$ & 3 & $4.62 \%$ \\
\hline $\begin{array}{l}\text { neišjungti mobilaus } \\
\text { / leaving mobile on }\end{array}$ & 5 & $8.93 \%$ & cutting in line & 3 & $\begin{array}{c}6.12 \\
\%\end{array}$ & $\begin{array}{l}\text { 打扰他人 } \\
\text { / disturbing others }\end{array}$ & 3 & $4.62 \%$ \\
\hline $\begin{array}{l}\text { nesilaikyti KET } \\
\text { / not observing traffic rules }\end{array}$ & 5 & $8.93 \%$ & $\begin{array}{l}\text { scratching } \\
\text { private parts }\end{array}$ & 3 & $\begin{array}{c}6.12 \\
\%\end{array}$ & $\begin{array}{l}\text { 抖腿 } \\
\text { / shaking legs }\end{array}$ & 3 & $4.62 \%$ \\
\hline $\begin{array}{l}\text { krapštyti nosį } \\
\text { / picking nose }\end{array}$ & 5 & $8.93 \%$ & $\begin{array}{l}\text { talking with } \\
\text { mouth full }\end{array}$ & 3 & $\begin{array}{c}6.12 \\
\%\end{array}$ & $\begin{array}{l}\text { 吵架 } \\
\text { / quarreling }\end{array}$ & 2 & $3.08 \%$ \\
\hline
\end{tabular}


Table 5. Overlap between most frequently cited immoral and uncultured behaviors

\begin{tabular}{|c|c|c|c|}
\hline & Overlap in Top 3 & Overlap in Top 10 & Overlap in Top 20 \\
\hline Mandarin Chinese & $3(100 \%)$ & $7(70 \%)$ & $12(60 \%)$ \\
\hline English & $0(0 \%)$ & $1(10 \%)$ & $2(5 \%)$ \\
\hline Lithuanian & $0(0 \%)$ & $3(30 \%)$ & $5(25 \%)$ \\
\hline
\end{tabular}


Table 6. Most frequently mentioned $\boldsymbol{b u}$ lunli and $\boldsymbol{b u}$ hefa behaviors. Numbers in brackets represent the number of participants in a condition. FREQ shows how many participants mentioned a given term. Percentages indicate the proportion of participants in the group who mentioned a given term in their lists.

\begin{tabular}{|c|c|c|c|c|c|}
\hline \multicolumn{3}{|c|}{ Bu lunli (52) } & \multicolumn{3}{|c|}{ Bu hefa (58) } \\
\hline ITEM & $\begin{array}{c}\text { FRE } \\
\mathbf{Q}\end{array}$ & $\%$ & ITEM & $\begin{array}{c}\text { FRE } \\
\mathbf{Q}\end{array}$ & $\%$ \\
\hline $\begin{array}{l}\text { 辱骂他人 } \\
\text { / insulting }\end{array}$ & 13 & $\begin{array}{c}25.00 \\
\%\end{array}$ & $\begin{array}{l}\text { 盗窃 } \\
\text { / stealing }\end{array}$ & 51 & $\begin{array}{c}87.93 \\
\%\end{array}$ \\
\hline $\begin{array}{l}\text { 打架/打人 } \\
\text { / fighting/hitting }\end{array}$ & 12 & $\begin{array}{c}23.08 \\
\%\end{array}$ & $\begin{array}{l}\text { 强奸 } \\
\text { / raping }\end{array}$ & 23 & $\begin{array}{c}39.66 \\
\%\end{array}$ \\
\hline $\begin{array}{l}\text { 随地吐痰 } \\
\text { / spitting }\end{array}$ & 10 & $\begin{array}{c}19.23 \\
\%\end{array}$ & $\begin{array}{l}\text { 杀人 } \\
\text { / killing }\end{array}$ & 19 & $\begin{array}{c}32.76 \\
\%\end{array}$ \\
\hline $\begin{array}{l}\text { 不孝 } \\
\text { / unfilial conduct }\end{array}$ & 10 & $\begin{array}{c}19.23 \\
\%\end{array}$ & $\begin{array}{l}\text { 不遵守交通规则 } \\
\text { /_not observing traffic rules }\end{array}$ & 18 & $\begin{array}{c}31.03 \\
\%\end{array}$ \\
\hline $\begin{array}{l}\text { 通奸 } \\
\text { / adultery }\end{array}$ & 10 & $\begin{array}{c}19.23 \\
\%\end{array}$ & $\begin{array}{l}\text { 欺骗 } \\
\text { / cheating }\end{array}$ & 14 & $\begin{array}{c}24.14 \\
\%\end{array}$ \\
\hline $\begin{array}{l}\text { 盗窃 } \\
\text { / stealing }\end{array}$ & 9 & $\begin{array}{c}17.31 \\
\%\end{array}$ & $\begin{array}{l}\text { 醉酒驾驶 } \\
\text { / drunk_driving }\end{array}$ & 12 & $\begin{array}{c}20.69 \\
\%\end{array}$ \\
\hline $\begin{array}{l}\text { 乱伦 } \\
\text { / incest }\end{array}$ & 9 & $\begin{array}{c}17.31 \\
\%\end{array}$ & $\begin{array}{l}\text { 打架/打人 } \\
\text { / fighting/hitting }\end{array}$ & 12 & $\begin{array}{c}20.69 \\
\%\end{array}$ \\
\hline $\begin{array}{l}\text { 随地大小便 } \\
\text { / urinating or defecating publicly }\end{array}$ & 8 & $\begin{array}{c}15.38 \\
\%\end{array}$ & $\begin{array}{l}\text { 放火 } \\
\text { / arson }\end{array}$ & 8 & $\begin{array}{c}13.79 \\
\%\end{array}$ \\
\hline $\begin{array}{l}\text { 不尊老 } \\
\text { / not respecting older people }\end{array}$ & 8 & $\begin{array}{c}15.38 \\
\%\end{array}$ & $\begin{array}{l}\text { 逃税 } \\
\text { / tax evasion }\end{array}$ & 7 & $\begin{array}{c}12.07 \\
\%\end{array}$ \\
\hline $\begin{array}{l}\text { 公共场合亲热 } \\
\text { / intimacy in public }\end{array}$ & 7 & $\begin{array}{c}13.46 \\
\%\end{array}$ & $\begin{array}{l}\text { 破坏公物 } \\
\text { / damaging public property }\end{array}$ & 5 & $\begin{array}{c}8.62 \\
\%\end{array}$ \\
\hline
\end{tabular}




\section{Appendices}

Appendix 1. Free-listing prompts for the studies reported in the present article

\section{Prompts}

The aim of this study is to learn which actions or behaviors are considered immoral [uncultured]. Please provide a list of actions and

English behaviors which, in your opinion, are immoral [uncultured]. Please list at least five examples. There are no correct answers, we are just interested in your opinion.

这项调查旨在了解常人认为的何谓不道德[不文明/不伦理/不合法]的动 作和行为。请列举出您个人认为是不道德 $[$ 不文明/不伦理/不合法]的动

Mandarin Chinese

Lithuanian 作或行为。请最少列举出 5 个例子。这里没有标准答案。我们对您个 人的意见感兴趣。

Šiuo tyrimu norime išsiaiškinti, kokius veiksmus ar poelgius žmonès laiko amoraliais [nekultūringais]. Prašome pateikti sąrašą veiksmų ar poelgių, kurie jūsų asmenine nuomone yra amoralūs [nekultūringi] (pateikite bent penkis pavyzdžius). Čia nèra teisingų ar klaidingu atsakymų, mums tik rūpi jūsų nuomonè. 


\section{Appendix 2. Terms used for quantitative analysis in the study}

\begin{tabular}{|c|c|c|c|}
\hline No. & EN & LT & $\mathrm{CN}$ \\
\hline 1 & killing/murder & žudyti & 杀人 \\
\hline 2 & stealing & vogti & 盗窃 \\
\hline 3 & cheating & sukčiauti & 欺骗 \\
\hline 4 & raping & prievartauti & 强奸 \\
\hline 5 & lying & meluoti & 说谎 \\
\hline 6 & animal abuse & kankinti gyvūnus & 残害动物 \\
\hline 7 & adultery & svetimauti & 通奸 \\
\hline 8 & paedophilia & pedofilija & 恋童癖 \\
\hline 9 & harming others & kenkti kitiems & 损人 \\
\hline 10 & violence & smurtauti & 暴力 \\
\hline 11 & bullying & tyčiotis & 欺负 \\
\hline 12 & betrayal & išduoti & 背叛 \\
\hline 13 & not respecting others & negerbti kitu & 不尊重他人 \\
\hline 14 & slandering & apkalbinèti & 背后议论 \\
\hline 15 & exploiting & išnaudoti & 剥削 \\
\hline 16 & being loud & triukšmauti & 公共场合喧华 \\
\hline 17 & littering & šiukšlinti & 乱扔垃圾 \\
\hline 18 & spitting & spjaudytis & 随地吐痰 \\
\hline 19 & cutting in line & lịsti be eilès & 插队 \\
\hline 20 & smoking in public & rūkyti viešumoje & 公共场合吸烟 \\
\hline 21 & insulting & ịžeidinèti & 辱骂他人 \\
\hline 22 & damaging public property & naikinti visuomenès turtą & 破坏公物 \\
\hline 23 & not observing traffic rules & nesilaikyti KET & 不遵守交通规则 \\
\hline 24 & swearing & keiktis & 说脏话 \\
\hline 25 & farting & persti & 放屁 \\
\hline
\end{tabular}




\begin{tabular}{|r|l|l|l|}
\hline 26 & picking_nose & krapštyti nosi & 挖鼻孔 \\
\hline 27 & burping & riaugèti & 打嗝 \\
\hline 28 & not washing & grubiai bendrauti & 不洗澡 \\
\hline 29 & being rude & valgyti pravira burna & 粗鲁对待他人 \\
\hline 30 & chewing with mouth open & negerbti vyresniu & 嚼着不闭嘴 \\
\hline 31 & not respecting older people & ignoruoti kitus & 不尊老 \\
\hline 32 & ignoring others & girtauti & 不理他人 \\
\hline 33 & alcohol abuse & pertraukinèti kitus & 酗酒 \\
\hline 34 & interrupting others & tuštintis viešai & 随意打断他人说话 \\
\hline 35 & urinating and defecating publicly & eiti per gatvę neleistinoje vietoje & 乱穿马路 \\
\hline 36 & jaywalking & muštis/mušti & 打架/打人 \\
\hline 37 & fighting/hitting & graffiti & 涂鸦 \\
\hline 38 & graffiti & valgyti netinkamose vietose & 在禁止吃饭的场合吃东西 \\
\hline 39 & eating in unsuitable places & & \\
\hline
\end{tabular}

\section{Appendix 3. Frequencies of terms in immoral and uncultured conditions (in percents) and differences between conditions}

\begin{tabular}{|c|c|c|c|c|c|c|c|c|c|c|}
\hline & & \multicolumn{3}{|l|}{$\mathbf{U S}$} & \multicolumn{3}{|c|}{ Mainland China } & \multicolumn{3}{|c|}{ Lithuania } \\
\hline $\begin{array}{l}\mathbf{N} \\
\mathbf{0}\end{array}$ & Term & $\begin{array}{l}\text { Immor } \\
\text { al }\end{array}$ & $\begin{array}{l}\text { Unculture } \\
\text { d }\end{array}$ & $\begin{array}{l}\text { Differenc } \\
\text { e }\end{array}$ & $\begin{array}{l}\text { Immora } \\
\text { l }\end{array}$ & $\begin{array}{l}\text { Unculture } \\
\text { d }\end{array}$ & $\begin{array}{l}\text { Differenc } \\
\text { e }\end{array}$ & $\begin{array}{l}\text { Immor } \\
\text { al }\end{array}$ & $\begin{array}{l}\text { Unculture } \\
\text { d }\end{array}$ & Difference \\
\hline 1 & killing/murder & 81.67 & 4.08 & 77.59 & 1.75 & 0 & 1.75 & 37.7 & 0 & 37.7 \\
\hline 2 & stealing & 78.33 & 12.24 & 66.09 & 14.04 & 3.08 & 10.96 & 42.62 & 1.79 & 40.83 \\
\hline 3 & cheating & 41.67 & 4.08 & 37.59 & 24.56 & 1.54 & 23.02 & 11.48 & 0 & 11.48 \\
\hline 4 & raping & 40.00 & 2.04 & 37.96 & 0 & 0 & 0 & 4.92 & 0 & 4.92 \\
\hline 5 & lying & 33.33 & 4.08 & 29.25 & 3.51 & 0 & 3.51 & 45.9 & 5.36 & 40.54 \\
\hline 6 & animal abuse & 15.00 & 2.04 & 12.96 & 1.75 & 0 & 1.75 & 13.11 & 1.79 & 11.32 \\
\hline 7 & adultery & 13.33 & 0 & 13.33 & 1.75 & 0 & 1.75 & 13.11 & 0 & 13.11 \\
\hline
\end{tabular}




\begin{tabular}{|c|c|c|c|c|c|c|c|c|c|c|}
\hline 8 & paedophilia & 13.33 & 0 & 13.33 & 0 & 0 & 0 & 0 & 0 & 0 \\
\hline 9 & harming others & 11.67 & 2.04 & 9.63 & 0 & 0 & 0 & 6.56 & 1.79 & 4.77 \\
\hline $\begin{array}{l}1 \\
0\end{array}$ & violence & 11.67 & 6.12 & 5.55 & 1.75 & 0 & 1.75 & 32.79 & 3.57 & 29.22 \\
\hline $\begin{array}{l}1 \\
1\end{array}$ & bullying & 3.33 & 10.20 & 6.87 & 5.26 & 0 & 5.26 & 29.51 & 16.07 & 13.44 \\
\hline $\begin{array}{l}1 \\
2\end{array}$ & betrayal & 1.67 & 0 & 1.67 & 0 & 0 & 0 & 18.03 & 0 & 18.03 \\
\hline $\begin{array}{l}1 \\
3\end{array}$ & $\begin{array}{l}\text { not respecting } \\
\text { others }\end{array}$ & 5.00 & 0 & 5 & 1.75 & 0 & 1.75 & 16.39 & 17.86 & 1.47 \\
\hline $\begin{array}{l}1 \\
4\end{array}$ & slandering & 0 & 0 & 0 & 5.26 & 1.54 & 3.72 & 11.48 & 16.07 & 4.59 \\
\hline $\begin{array}{l}1 \\
5\end{array}$ & exploiting & 6.67 & 0 & 6.67 & 0 & 0 & 0 & 11.48 & 0 & 11.48 \\
\hline $\begin{array}{l}1 \\
6\end{array}$ & being loud & 0 & 22.45 & 22.45 & 49.12 & 58.46 & 9.34 & 1.64 & 30.36 & 28.72 \\
\hline $\begin{array}{l}1 \\
7\end{array}$ & littering & 3.33 & 4.08 & 0.75 & 47.37 & 67.69 & 20.32 & 1.64 & 30.36 & 28.72 \\
\hline $\begin{array}{l}1 \\
8\end{array}$ & spitting & 0 & 14.29 & 14.29 & 42.11 & 67.69 & 25.58 & 0 & 39.29 & 39.29 \\
\hline $\begin{array}{l}1 \\
9\end{array}$ & cutting in line & 0 & 6.12 & 6.12 & 26.32 & 27.69 & 1.37 & 0 & 8.93 & 8.93 \\
\hline $\begin{array}{l}2 \\
0\end{array}$ & smoking in public & 0 & 2.04 & 2.04 & 22.81 & 27.69 & 4.88 & 1.64 & 10.71 & 9.07 \\
\hline $\begin{array}{l}2 \\
1\end{array}$ & insulting & 0 & 0 & 0 & 14.04 & 15.38 & 1.34 & 3.28 & 7.14 & 3.86 \\
\hline $\begin{array}{l}2 \\
2\end{array}$ & $\begin{array}{l}\text { damaging public } \\
\text { property }\end{array}$ & 1.67 & 0 & 1.67 & 10.53 & 6.15 & 4.38 & 1.64 & 1.79 & 0.15 \\
\hline $\begin{array}{l}2 \\
3\end{array}$ & $\begin{array}{l}\text { not observing } \\
\text { traffic rules }\end{array}$ & 0 & 6.12 & 6.12 & 10.53 & 15.38 & 4.85 & 0 & 8.93 & 8.93 \\
\hline $\begin{array}{l}2 \\
4\end{array}$ & swearing & 3.33 & 26.53 & 23.2 & 5.26 & 24.62 & 19.36 & 4.92 & 48.21 & 43.29 \\
\hline $\begin{array}{l}2 \\
5\end{array}$ & farting & 1.67 & 26.53 & 24.86 & 0 & 0 & 0 & 0 & 1.79 & 1.79 \\
\hline $\begin{array}{l}2 \\
6\end{array}$ & picking nose & 0 & 24.49 & 24.49 & 0 & 0 & 0 & 0 & 8.93 & 8.93 \\
\hline $\begin{array}{l}2 \\
7\end{array}$ & burping & 0 & 22.45 & 22.45 & 0 & 0 & 0 & 0 & 7.14 & 7.14 \\
\hline $\begin{array}{l}2 \\
8\end{array}$ & not washing & 0 & 14.29 & 14.29 & 0 & 0 & 0 & 0 & 1.79 & 1.79 \\
\hline $\begin{array}{l}2 \\
9\end{array}$ & being rude & 0 & 12.24 & 12.24 & 1.75 & 1.54 & 0.21 & 0 & 10.71 & 10.71 \\
\hline $\begin{array}{l}3 \\
0\end{array}$ & $\begin{array}{l}\text { chewing with } \\
\text { mouth open }\end{array}$ & 0 & 12.24 & 12.24 & 0 & 0 & 0 & 0 & 10.71 & 10.71 \\
\hline
\end{tabular}




\begin{tabular}{|c|c|c|c|c|c|c|c|c|c|c|}
\hline $\begin{array}{l}3 \\
1\end{array}$ & $\begin{array}{l}\text { not respecting } \\
\text { older people }\end{array}$ & 0 & 0 & 0 & 1.75 & 1.54 & 0.21 & 1.64 & 14.29 & 12.65 \\
\hline $\begin{array}{l}3 \\
2\end{array}$ & ignoring others & 0 & 2.04 & 2.04 & 1.75 & 0 & 1.75 & 6.56 & 12.50 & 5.94 \\
\hline $\begin{array}{l}3 \\
3\end{array}$ & alcohol abuse & 1.67 & 4.08 & 2.41 & 0 & 0 & 0 & 9.84 & 12.50 & 2.66 \\
\hline $\begin{array}{l}3 \\
4\end{array}$ & interrupting others & 0 & 4.08 & 4.08 & 1.75 & 1.54 & 0.21 & 1.64 & 12.50 & 10.86 \\
\hline $\begin{array}{l}3 \\
5\end{array}$ & $\begin{array}{l}\text { urinating and } \\
\text { defecating publicly }\end{array}$ & 0 & 0 & 0 & 8.77 & 10.77 & 2 & 1.64 & 1.79 & 0.15 \\
\hline $\begin{array}{l}3 \\
6\end{array}$ & jaywalking & 0 & 0 & 0 & 0 & 9.23 & 9.23 & 0 & 0 & 0 \\
\hline $\begin{array}{l}3 \\
7\end{array}$ & fighting/hitting & 10.00 & 8.16 & 1.84 & 8.77 & 9.23 & 0.46 & 3.28 & 3.57 & 0.29 \\
\hline $\begin{array}{l}3 \\
8\end{array}$ & graffiti & 0 & 0 & 0 & 5.26 & 9.23 & 3.97 & 0 & 1.79 & 1.79 \\
\hline \multirow[t]{2}{*}{$\begin{array}{l}3 \\
9\end{array}$} & $\begin{array}{l}\text { eating in } \\
\text { unsuitable places }\end{array}$ & 0 & 0 & 0 & 3.51 & 9.23 & 5.72 & 0 & 0 & 0 \\
\hline & & $\begin{array}{l}\text { Avrg. } \\
\text { diff. }\end{array}$ & & 13.36 & & & 4.37 & & & 12.55 \\
\hline
\end{tabular}

